American Journal of Applied Sciences 5 (5): 512-518, 2008

ISSN 1546-9239

(C) 2008 Science Publications

\title{
Waste Characterization in Steel Casting and Recycling Opportunities in Europe
}

\author{
Silvia Fiore, Maria Chiara Zanetti and Barbara Ruffino \\ DITAG, Politecnico di Torino, Corso Duca degli Abruzzi, 24 \\ 10129 Torino, Italy
}

\begin{abstract}
The wastes coming from a steel foundry located in Italy, producing about $600,000 \mathrm{t} / \mathrm{y}$ of steel slabs, are considered in this work. The plant produces about 143,000 t/y of wastes, made of furnace and ladle slags (84\%), pelletized dust (8\%) and oxidised shaving (8\%). The waste materials have been characterised by means of particle-size and chemical analyses, and some reuse/recycle possibilities are considered. The recycle as inert material of the slags was evaluated by means of several leaching tests according to the Italian (UNI10802 test, equivalent to EN 12457/2 test), French (AFNOR X31-210 test), Danish and European Community (EN 12457/4 test) regulations. The requirements of the above mentioned regulations were compared and discussed. The possibility of landfilling the materials as inert or not dangerous wastes according to Italian Law (DM 3/8/2005) and European Community regulation (Decision of European Community Council $\mathrm{N}^{\circ} 2003 / 33$ ) was also considered.
\end{abstract}

Keywords: foundry waste recycling, steel casting, leaching test, waste characterization.

\section{INTRODUCTION}

The reuse as inert material of the industrial wastes is a primary issue considered worldwide. The regulations are generally based on the results of leaching tests, aimed to evaluate the potential impact produced by the industrial waste in a natural context. Leaching tests are also employed in numerous Countries to evaluate the waste acceptance requirements in different landfill categories. A reliable leaching test must take into account both physical (particle-size distribution, temperature, porosity, procedure to put in contact solid and liquid phases) and chemical parameters $(\mathrm{pH}$, redox potential and kinetic aspects), which determine the release of pollutants from the solid phase to the leachate, simulating the environmental conditions of which the waste would become part.

The international regulations foresee codified procedures to perform the leaching tests, and a waste material may be inserted in a natural context only if the pollutants concentration values determined in the leachate are lower than the limits prescribed by each Country.

In this work the results of several leaching tests performed on foundry wastes according to the Italian
(UNI10802 test, equivalent to EN 12457/2 test), French (AFNOR X31-210 test), Danish and European Community (EN 12457/4 test) regulations are compared and discussed. The possibility of landfilling the considered materials as inert or not dangerous wastes according to Italian Law (DM 3/8/2005) and European Community regulation (Decision of European Community Council $\mathrm{N}^{\circ} 2003 / 33$ ), respectively based on EN 12457/2 test and on EN 12457/4 test, was also considered.

Table 1: Italian limits concerning the reuse of not dangerous wastes as inert material (Italian Law DM 5/2/98 and DM 186/2006)

\begin{tabular}{lclc}
\hline $\mathrm{NO}_{3}{ }^{-}(\mathrm{mg} / \mathrm{l})$ & 50 & $\mathrm{~V}(\mu \mathrm{g} / \mathrm{l})$ & 250 \\
$\mathrm{~F}^{-}(\mathrm{mg} / \mathrm{l})$ & 1.5 & $\mathrm{As}(\mu \mathrm{g} / \mathrm{l})$ & 50 \\
$\mathrm{SO}_{4}{ }^{-}(\mathrm{mg} / \mathrm{l})$ & 250 & $\mathrm{Cd}(\mu \mathrm{g} / \mathrm{l})$ & 5 \\
$\mathrm{Cl}^{-}(\mathrm{mg} / \mathrm{l})$ & $200 / 100^{*}$ & $\mathrm{Tot} \mathrm{Cr}(\mu \mathrm{g} / \mathrm{l})$ & 50 \\
$\mathrm{CN}^{-}(\mathrm{mg} / \mathrm{l})$ & 50 & $\mathrm{~Pb}(\mu \mathrm{g} / \mathrm{l})$ & 50 \\
$\mathrm{Ba}(\mathrm{mg} / \mathrm{l})$ & 1 & $\mathrm{Se}(\mu \mathrm{g} / \mathrm{l})$ & 10 \\
$\mathrm{Cu}(\mathrm{mg} / \mathrm{l})$ & 0.05 & $\mathrm{Hg}(\mu \mathrm{g} / \mathrm{l})$ & 1 \\
$\mathrm{Zn}(\mathrm{mg} / \mathrm{l})$ & 3 & asbestos & 30 \\
$\mathrm{Be}(\mu \mathrm{g} / \mathrm{l})$ & 10 & $\mathrm{COD}(\mathrm{mg} / \mathrm{l})$ & 30 \\
$\mathrm{Co}(\mu \mathrm{g} / \mathrm{l})$ & 250 & $\mathrm{pH}$ & $5.5-12.0$ \\
$\mathrm{Ni}(\mu \mathrm{g} / \mathrm{l})$ & 10 & & \\
\hline
\end{tabular}

*DM 186/2006 maintained all DM 5/2/98 limits, with the exception of chlorides, for which the limit was halved.

Corresponding Author: $\quad$ Silvia Fiore, DITAG, Politecnico di Torino, corso Duca degli Abruzzi 24, 10129 Torino, Italy, Tel: +39-0115647613, Fax: +39-0115647699, E-mail: silvia.fiore@ polito.it 
At the moment Italian law concerning leaching tests to evaluate the reuse of not dangerous wastes in direct contact with the environment is in a transition phase; in fact the leaching test established by DM 5/2/98 has been replaced in 2006 by UNI 10802 test, equivalent to EN 12457/2 test (Italian law DM $186 / 2006)$. In this work the results of both leaching tests are presented, to underline the limits of the abandoned leaching test. Italian law limits concerning the reuse of not dangerous wastes are reported in Table 1 .

Table 2: French limits concerning ashes from waste incineration (French Environment Ministry Circular 5/9/1994)

\begin{tabular}{|c|c|c|c|}
\hline & Valorizable & Maturable & Disposable \\
\hline Soluble fraction (\%) & $<5$ & $5-10$ & $>10$ \\
\hline $\mathrm{SO}_{4}{ }^{=}(\mathrm{g} / \mathrm{kg})$ & $<10$ & $10-15$ & $>15$ \\
\hline TOC $(\mathrm{g} / \mathrm{kg})$ & $<1.5$ & $1.5-2$ & $>2$ \\
\hline $\mathrm{Hg}(\mathrm{mg} / \mathrm{kg})$ & $<0.2$ & $0.2-0.4$ & $>0.4$ \\
\hline $\mathrm{Pb}(\mathrm{mg} / \mathrm{kg})$ & $<10$ & $10-50$ & $>50$ \\
\hline $\mathrm{Cd}(\mathrm{mg} / \mathrm{kg})$ & $<1$ & $1-2$ & $>2$ \\
\hline As (mg/kg) & $<2$ & $2-4$ & $>4$ \\
\hline $\mathrm{Cr}^{+6}(\mathrm{mg} / \mathrm{kg})$ & $<1$ & $1-2$ & $>2$ \\
\hline
\end{tabular}

Table 3: European Community (Decision of European Community Council $\mathrm{N}^{\circ} 2003 / 33$ ) and Italian law (DM 3/8/2005) requirements for landfill disposal, both considering a $\mathrm{L} / \mathrm{S}=10$.

\begin{tabular}{lcc}
\hline & Inert wastes & $\begin{array}{c}\text { Not dangerous } \\
\text { wastes }\end{array}$ \\
\hline $\mathrm{As}(\mathrm{mg} / \mathrm{kg})$ & 0.5 & 2 \\
$\mathrm{Ba}(\mathrm{mg} / \mathrm{kg})$ & 20 & 100 \\
$\mathrm{Cd}(\mathrm{mg} / \mathrm{kg})$ & 0.04 & $1 / 0.2^{*}$ \\
$\mathrm{tot} \mathrm{Cr}(\mathrm{mg} / \mathrm{kg})$ & 0.5 & 10 \\
$\mathrm{Cu}(\mathrm{mg} / \mathrm{kg})$ & 2 & 50 \\
$\mathrm{Hg}(\mathrm{mg} / \mathrm{kg})$ & 0.01 & $0.2 / 0.05^{*}$ \\
$\mathrm{Mo}(\mathrm{mg} / \mathrm{kg})$ & 0.5 & 10 \\
$\mathrm{Ni}(\mathrm{mg} / \mathrm{kg})$ & 0.4 & 10 \\
$\mathrm{~Pb}(\mathrm{mg} / \mathrm{kg})$ & 0.5 & 10 \\
$\mathrm{Sb}(\mathrm{mg} / \mathrm{kg})$ & 0.06 & 0.7 \\
$\mathrm{Se}(\mathrm{mg} / \mathrm{kg})$ & 0.1 & 0.5 \\
$\mathrm{Zn}(\mathrm{mg} / \mathrm{kg})$ & 4 & 50 \\
$\mathrm{Cl}-(\mathrm{mg} / \mathrm{kg})$ & 800 & 15,000 \\
$\mathrm{~F}^{-}(\mathrm{mg} / \mathrm{kg})$ & 10 & 150 \\
$\mathrm{SO}{ }_{4}{ }^{-}(\mathrm{mg} / \mathrm{kg})$ & 1,000 & 20,000 \\
$\mathrm{DOC}(\mathrm{mg} / \mathrm{kg})$ & 500 & 800 \\
$\mathrm{TDS}(\mathrm{mg} / \mathrm{kg})$ & 4,000 & 60,000 \\
\hline *Italian law foresees lower requirements concerning Cd and $\mathrm{Hg}$ about \\
not dangerous wastes landfill disposal.
\end{tabular}

The AFNOR X31-210 leaching test is the reference procedure adopted in France (French Environment Ministry Circular 5/9/1994) to evaluate the ecotoxicologic properties of ashes from waste incineration, that may be defined valorizable (directly reusable as inert material), maturable (reusable as inert material after a maturation period or a pre-treatment), or disposable (in a second category landfill, that is for not dangerous wastes), as shown in Table 2.

The EN 12457/4 test is adopted by the European Community to evaluate the required landfill disposal (Decision of European Community Council $\mathrm{N}^{\circ} 2003 / 33$ ), considering the concentration limits shown in Table 3.

The EN 12457/3 test is employed by the Danish Country (Danish Ministry of Energy and Environment Statutory Order $\mathrm{N}^{\circ} 655$ of $27 / 6 / 2000$ ) in order to assess the reuse of residual products and soil in building and construction work. Danish regulations divide these kinds of wastes, generally all reusable for the construction of roads, paths, squares, sound-absorbing walls, ramps, dykes, dams, railway embankments, pipe/cable trenches, refilling floors and foundations, in first, second and third category materials, depending on the higher or less possibility of penetration of rainwater (see Table 4). Recycle Category 1 has no requirements and/or limitations.

Table 4:Danish limits for the reuse of residual products and soil in building and construction work (Danish Ministry of Energy and Environment Statutory Order $N^{\circ} 655$ of $27 / 6 / 2000$ )

\begin{tabular}{|c|c|c|c|}
\hline & $\begin{array}{c}\text { Recycle } \\
\text { Category } 1\end{array}$ & $\begin{array}{c}\text { Recycle } \\
\text { Category } 2\end{array}$ & $\begin{array}{c}\text { Recycle } \\
\text { Category } 3\end{array}$ \\
\hline & \multicolumn{3}{|c|}{ Solid content (mg/kg of dry matter) } \\
\hline As & $0-20$ & $>20$ & $>20$ \\
\hline $\mathrm{Pb}$ & $0-40$ & $>40$ & $>40$ \\
\hline $\mathrm{Cd}$ & $0-0.5$ & $>0.5$ & $>0,5$ \\
\hline Tot $\mathrm{Cr}$ & $0-500$ & $>500$ & $>500$ \\
\hline $\mathrm{Cr}(\mathrm{VI})$ & $0-20$ & $>20$ & $>20$ \\
\hline $\mathrm{Cu}$ & $0-500$ & $>500$ & $>500$ \\
\hline $\mathrm{Hg}$ & $0-1$ & $>1$ & $>1$ \\
\hline $\mathrm{Ni}$ & $0-30$ & $>30$ & $>30$ \\
\hline \multirow[t]{2}{*}{$\mathrm{Zn}$} & $0-500$ & $>500$ & $>500$ \\
\hline & \multicolumn{3}{|c|}{ Concentration in the leachate $(\mu \mathrm{g} / \mathrm{l})$} \\
\hline $\mathrm{Cl}^{-}$ & $0-150,000$ & $0-150,000$ & $\begin{array}{l}150,000- \\
3,000,000\end{array}$ \\
\hline $\mathrm{SO}_{4}=$ & $0-250,000$ & $0-250,000$ & $\begin{array}{l}250,000- \\
4,000,000\end{array}$ \\
\hline $\mathrm{Na}$ & $0-100,000$ & $0-100,000$ & $\begin{array}{l}100,000- \\
1,500,000\end{array}$ \\
\hline As & $0-8$ & $0-8$ & $8-50$ \\
\hline $\mathrm{Ba}$ & $0-300$ & $0-300$ & $300-4,000$ \\
\hline $\mathrm{Pb}$ & $0-10$ & $0-10$ & $10-100$ \\
\hline $\mathrm{Cd}$ & $0-2$ & $0-2$ & $2-40$ \\
\hline Tot $\mathrm{Cr}$ & $0-10$ & $0-10$ & $10-500$ \\
\hline $\mathrm{Cu}$ & $0-45$ & $0-45$ & $45-2,000$ \\
\hline $\mathrm{Hg}$ & $0-0.1$ & $0-0.1$ & $0.1-1$ \\
\hline $\mathrm{Mn}$ & $0-150$ & $0-150$ & $150-1,000$ \\
\hline $\mathrm{Ni}$ & $0-10$ & $0-10$ & $10-70$ \\
\hline $\mathrm{Zn}$ & $0-100$ & $0-100$ & $100-1,500$ \\
\hline
\end{tabular}

The procedures adopted by the all above mentioned leaching tests are schematised in Table 5. Considering 
Table 5: Scheme of the procedures adopted in the performed leaching tests

\begin{tabular}{|c|c|c|c|c|}
\hline & $\begin{array}{l}\text { Abandoned Italian } \\
\text { leaching test } \\
\text { (DM 5/2/98) }\end{array}$ & $\begin{array}{c}\text { Actual Italian } \\
\text { leaching test (UNI } \\
10802)\end{array}$ & $\begin{array}{c}\text { Test AFNOR X31- } \\
210\end{array}$ & Test EN 12457-4 \\
\hline Field of application & $\begin{array}{l}\text { Recovery of not } \\
\text { dangerous wastes }\end{array}$ & $\begin{array}{l}\text { Recovery and } \\
\text { landfilling of not } \\
\text { dangerous wastes }\end{array}$ & $\begin{array}{l}\text { Ecotoxicologic } \\
\text { characterization of } \\
\text { ashes from waste } \\
\text { incinerating }\end{array}$ & $\begin{array}{l}\text { Recovery and } \\
\text { landfilling of not } \\
\text { dangerous wastes }\end{array}$ \\
\hline Kind of test/length & $\begin{array}{l}\text { Batch sequential/ } 16 \\
\text { days }\end{array}$ & Batch/ 24 hours & Batch/ 24 hours & Batch/ 24 hours \\
\hline $\begin{array}{l}\text { a)sample amount, b)particle-size } \\
\text { dimensions, c)temperature, } \\
\text { d)solid/liquid ratio, e)stirring }\end{array}$ & $\begin{array}{l}\text { a) } 100 \mathrm{~g}, \text { b)d }<10 \mathrm{~mm} \text {, } \\
\left.\text { c) } 20^{\circ} \mathrm{C} \pm 2, \mathrm{~d}\right) \mathrm{S} / \mathrm{L} \quad 1: 5 \\
\text { e)no }\end{array}$ & $\begin{array}{l}\text { a) } 100 \mathrm{~g}, \mathrm{~b}) \mathrm{d}<4 \mathrm{~mm} \text {, } \\
\left.\text { c) } 20^{\circ} \mathrm{C} \pm 5, \quad \mathrm{~d}\right) \mathrm{S} / \mathrm{L} \\
\text { 1:10, e)yes, } 10 \mathrm{rpm}\end{array}$ & $\begin{array}{l}\text { a) } 100 \text { g, b)d }<4 \\
\text { mm, c) } 20^{\circ} \mathrm{C} \pm 5, \\
\text { d)S/L } 1: 10, \text { e)yes, } \\
60 \mathrm{rpm}\end{array}$ & $\begin{array}{l}\text { a) } 100 \mathrm{~g}, \mathrm{~b}) \mathrm{d}<10 \mathrm{~mm} \text {, } \\
\text { c) } 20^{\circ} \mathrm{C} \pm 5, \quad \text { d)S/L } \\
1: 10, \text { e)yes, } 10 \mathrm{rpm}\end{array}$ \\
\hline Pollutants concentration limits & Table 1 & See Table 1 & Table 2 & See Table 4 \\
\hline
\end{tabular}

the concentration limits fixed by the Italian, French, Danish and European Community regulations and the procedures of the Italian (DM 5/2/98), AFNOR X31210 and EN12457/2-4 leaching tests, the authors may underline the following aspects:

- The Italian test according to DM $5 / 2 / 98$ is a sequential batch test: the liquid phase is changed after 2, 8, 24, 48, 72, 102, 168, 384 hours after the beginning of the test, and the batch reactor is not stirred. Each liquid fraction is chemically characterized, and the sum of the concentrations for each parameter of the eight liquid phases must be compared with the Italian law limits (see Table 1). The AFNOR X31-210, EN 12457-2, and EN12457-4 tests are batch tests based on a single liquid phase, put in a stirred reactor, and analysed after 24 hours; they all employ a solid/liquid ratio equal to $1: 10$ b.w., and they are different about the waste particle-size dimensions and the stirring speed (see Table 5)

- The authors compare the results of the EN 12457/4 test with Danish limits for the reuse of residual products and soil in building and construction work (Danish Ministry of Energy and Environment Statutory Order $N^{\circ} 655$ of $\left.27 / 6 / 2000\right)$. Really Danish regulations foresee the EN 12457/3 test, which adopts a solid/liquid ratio equal to $1: 2$, thus the authors consider more conservative conditions

- Italian limits concerning the reuse of not dangerous wastes (see Table 1) are comparable to European Community limits for the landfilling of inert wastes (see Table 3, considering a solid/liquid ratio equal to $1: 10$ b.w.), and respectively less precautionary than French limits for the reuse (see Table 2)

- French limits concerning valorizable wastes (see Table 2) are not very restrictive, in fact they are less precautionary than Italian and Danish limits for the reuse and than European Community limits for the landfilling of not dangerous wastes (see Table 3)

- Danish limits for Recycle Category 1 (see Table 4) are very restrictive, much more than French limits for the reuse and than European Community limits for the landfilling of inert wastes (see Table 3), with the exception of chlorides and sulphates limits; however the fact that Danish regulations refer to a leaching test that employs a very low solid/liquid ratio must be considered. Moreover, Danish limits consider that only a part of pollutant substances are released in water, European Community instead hypothesize that all the pollutant substances are released in water.

A Steel Foundry In Italy: The Considered CaseStudy: The wastes coming out from a steel foundry located in northern Italy, producing about 600,000 t/y of mild steel slabs, are considered in this work. The productive process is made of the following phases: preparation of the feed, casting in an Electric Arc Furnace (EAF), continuous casting on six lines and forming of the slabs in two rolling mills. The feed is

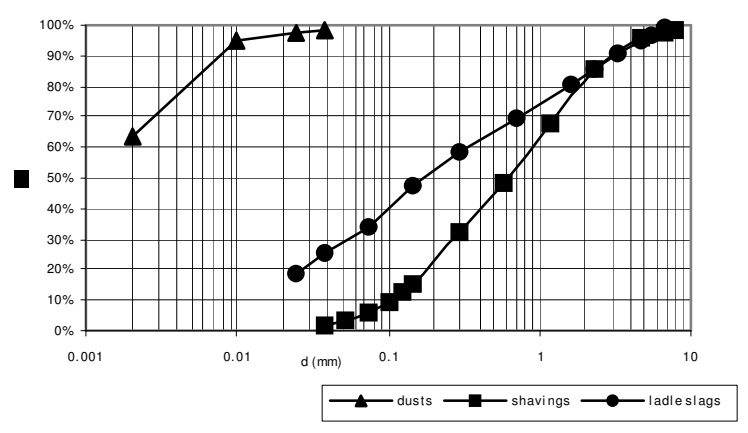

Fig.1: Particle-size analysis of some wastes produced in the steelmaking plant 
Am. J. Applied Sci., 5 (5): 512-518, 2008

Table .6: Chemical analysis of some wastes produced in the steelmaking plant

\begin{tabular}{|llllllllllllll|}
\hline & $\mathrm{Na}$ & $\mathrm{K}$ & $\mathrm{Mg}$ & $\mathrm{Mn}$ & $\mathrm{Fe}$ & $\mathrm{Zn}$ & $\mathrm{Ca}$ & $\mathrm{Pb}$ & $\mathrm{Cd}$ & $\mathrm{Cu}$ & $\mathrm{Ni}$ & $\mathrm{Cr}$ & $\mathrm{Al} \mid$ \\
sample & $\mathrm{mg} / \mathrm{kg}$ & $\mathrm{mg} / \mathrm{kg}$ & $\%$ & $\%$ & $\%$ & $\mathrm{mg} / \mathrm{kg}$ & $\%$ & $\mathrm{mg} / \mathrm{kg}$ & $\mathrm{mg} / \mathrm{kg}$ & $\mathrm{mg} / \mathrm{kg}$ & $\mathrm{mg} / \mathrm{kg}$ & $\mathrm{mg} / \mathrm{kg}$ & $\%$ \\
\hline Dusts & 14159 & 13898 & 1.4 & 1.1 & 15.5 & 289289 & 2.6 & 51216 & 371 & 3142 & 254 & 2121 & 1.2 \\
Shavings & 102 & 65 & 0.8 & 0.4 & 62.4 & 126 & 1.5 & $<150$ & $<10$ & 2111 & 804 & 1758 & 1.1 \\
Ladle slag $>10 \mathrm{~mm}$ & 440 & 441 & 12.5 & 4.4 & 3.9 & 67 & 18.5 & $<150$ & $<10$ & 71 & 47 & 654,7 & 4.8 \\
Ladle slag< $10 \mathrm{~mm}$ & 601 & 348 & 15.6 & 0.8 & 1.7 & 62 & 26.4 & $<150$ & $<10$ & 56 & 48 & 171,9 & 3.2 \\
Ladle slag & 585 & 357 & 15.2 & 1.2 & 1.9 & 63 & 26.6 & $<150$ & $<10$ & 58 & 48 & 220,2 & 3.3 \\
Grey furnace slag & 719 & 388 & 5.6 & 2.9 & 15.5 & 920 & 14.9 & 176 & $<10$ & 271 & 107 & 2663 & 2.1 \\
Black furnace slag & 921 & 367 & 5.6 & 3.1 & 23.5 & 632 & 8.2 & $<150$ & $<10$ & 231 & 80 & 4383 & 2.7 \\
Total furnace slag & 881 & 371 & 5.6 & 3.0 & 21.9 & 689 & 9.6 & $<150$ & $<10$ & 239 & 85 & 4039 & 2.5 \\
Total slag & 851 & 370 & 6.6 & 2.8 & 19.9 & 627 & 11.2 & $<150$ & $<10$ & 221 & 81 & 3657 & 2.6 \\
\hline
\end{tabular}

made of ferrous scraps $(750,000 \mathrm{t} / \mathrm{y}$, coming from Italy, France and Great Britain), put into baskets with sods of lime as slag forming agent, and carbonaceous scraps to avoid the overblowing of the bath. The molten metal obtained in the casting furnace is transferred in preheated ladles and then in the ladle furnace, where the refining operations (alligation, nodularization and desulphurisation) take place. The continuous casting is performed on six lines in copper ingot moulds, equipped with water-cooling systems. The slabs are then carried on a mobile guide, cooled with nebulized water, hot-cut and formed in two rolling mills, different about the section of the slabs. The semi-finished products are finally cooled and cut according to the requested specifications.

The main wastes produced in steelmaking operations are metal dusts, slags and gaseous emissions ${ }^{[1]}$. Particulate matter and gaseous products are usually collected together in a gas cleaning system and listed as hazardous waste. The composition of this material depends on the scrap and on furnace additives: usually lime, iron, zinc, chromium and nickel oxides (when stainless steel is produced), and burnt residues of oil and grease are the main components of the EAF dust. The slugs collected in the melting furnace and in the ladles are essentially composed by lime and oxidized iron, zinc, chromium, nickel, manganese, phosphorous, silicon, and carbon.

The considered foundry produces about 143,000 t/y of wastes, made of the following materials: furnace and ladle slags $(84 \%)$, pelletized dust coming from dust abatement plants $(8 \%)$, oxidised shavings from the slabs cut $(8 \%)$. There are three types of slags: the furnace produces a black (about the $80 \%$ b.w. of the furnace slag, 86,000 t/y ) and a grey (about the 20\% b.w. of the furnace slag, equal to 22,000 t/y) slag, both made of heterogeneous dimension aggregates; the ladle slag (about 12,000 t/y) are a light grey dust material, containing glassy aggregates (dimensions above $1 \mathrm{~mm}$, about the $10 \%$ b.w. of the ladle slag). After the melting the slags are collected and cooled, then undergo to a magnetic separation to recover the ferrous fraction (reused in the feed baskets); therefore the waste materials named "slags" in this work are the amagnetic fraction resulting from this operation. The dusts (about $11,000 \mathrm{t} / \mathrm{y}$, containing about the $25-30 \%$ b.w. of zinc) coming out from the dust abatement plant are pelletized (dimensions equal to $0.5-2 \mathrm{~cm}$ ) to minimize the problems connected with the transport of this material; the shavings from cut operations (about 12,000 t/y) are oxidised steel scraps of heterogeneous dimensions (average $0.5 \mathrm{~cm}$ ), separated from process waters by means of hydrocyclones and then thickened in pools.

The above-described waste materials have been characterised by means of particle-size and chemical analyses, and some reuse/recycle possibilities are hypothesized. The recycle in industrial processes was proposed for the dusts and the shavings. The recycle as inert material of the slags was evaluated by means of the Italian (DM 5/2/98 and EN12457-2), French (test AFNOR X31-210) and European Community (EN 12457-4) leaching tests. The requirements of the Italian,

French, Danish and European Community regulations were compared and discussed. The possibility of landfilling the materials as inert or not dangerous wastes according to European Community regulation (Decision of European Community Council N²003/33) was also considered.

\section{MATERIALS AND METHODS}

All the reagents employed are A.C.S. grade and the flasks and the glassware are A class. All the analyses were performed on dried samples.

The particle-size analysis was realized on samples of about $5 \mathrm{~kg}$ reduced to a mass of about $400 \mathrm{~g}$ by means of a Jones splitter, using a Ro-Tap Tyler mechanical siever equipped with six Tyler mesh sieves (2/4 ratio) for $10 \mathrm{~min}$. All the weighting operations were performed by means of a balance $(0.01 \mathrm{~g}$ 
sensitivity). The inflow samples were at first wet sieved at a 0.025 and $0.038 \mathrm{~mm}$ dimension before the particle size analysis. The particle-size analysis below the 0.025 $\mathrm{mm}$ dimension was performed by means of the Andreasen apparatus. The calcinations loss was evaluated by roasting $2 \mathrm{~g}$ of dried sample at the temperature of $900^{\circ} \mathrm{C}$ for $3 \mathrm{~h}$. The weight difference $(\%$ b.w.) between the starting sample and the roasted one gives the searched value.

The metals ( $\mathrm{Na}, \mathrm{K}, \mathrm{Mg}, \mathrm{Mn}, \mathrm{Fe}, \mathrm{Cr}, \mathrm{Zn}, \mathrm{Pb}, \mathrm{Cd}$, $\mathrm{Cu}, \mathrm{Ca}, \mathrm{Ni}$ ) contents were obtained through an acid digestion of $0.5 \mathrm{~g}$ sand with $6 \mathrm{ml}$ of $32 \%$ hydrochloric acid and $2 \mathrm{ml}$ of $65 \%$ nitric acid in a microwave oven. The digested samples were filtrated on a Whatman grade 542 filters and on the obtained solutions the metals contents determination was performed by means of a Perkin-Elmer ICP Optima 200 DV.

The aluminium content was measured through an acid digestion of $0.25 \mathrm{~g}$ sand with $2.5 \mathrm{ml}$ of $96 \%$ sulphuric acid and $2.5 \mathrm{ml}$ of $85 \%$ phosphoric acid in a microwave oven. 5 millilitres of fluoridric acid were added to the digested samples and a new digestion phase was performed. The digested samples were filtrated on a Whatman grade 542 filters and on the obtained solutions the aluminium content determination was performed by means of a Perkin-Elmer ICP Optima 200 DV.

The calcium carbonate content was determined treating the samples with $\mathrm{HCl}$ and back titrating the liquid phases with $\mathrm{NaOH}$.

\section{RESULTS AND DISCUSSION}

The characterization of the waste materials concerned the particle-size analysis and the determination of sodium, potassium, magnesium, calcium, iron, manganese, zinc, lead, cadmium, copper, nickel, chromium, aluminium, and calcium carbonate contents.

The results of the particle-size analysis, reported in Figure 1, show the heterogeneity of the Ladle Slag and of the Shavings, and the fine particle-size of the Dusts (about the $63 \%$ has dimensions below $2 \mu \mathrm{m}$ ). The furnace slags didn't undergo a particle-size analysis because made of huge and irregular aggregates and the fraction above $10 \mathrm{~mm}$ was eliminated from the sample Ladle Slag.

The chemical characterization regarded the samples Black Furnace Slag, Grey Furnace Slag, Ladle Slag, Dusts and Shavings. A mixture of the furnace slags, defined Total Furnace Slag, was prepared considering the relative abundance of the two components (20\% Grey Slag and $80 \%$ Black Slag). As well as the sample Ladle Slag, fractions above and below $10 \mathrm{~mm}$ were characterized individually. Moreover, a sample representative of all the slugs (made of $10 \%$ of Ladle Slag and $90 \%$ of Total Furnace Slag), named Total Slag, was analyzed.

The results of the chemical analyses, reported in Table 6, show the composition of the Dusts: $29 \%$ zinc, $15 \%$ iron, $5 \%$ lead and about $1-2 \%$ of sodium, potassium, magnesium, manganese and calcium. The calcium and magnesium contents determined in the samples, particularly high in the Ladle Slag, may be related to the use of granular and magnesium lime; the zinc, iron, lead, manganese, chromium, cadmium and nickel contents derive mainly from the composition of the scraps, but also from the additives employed in the steelmaking process. The sample Shavings is composed essentially by iron (more than 62\%) and by minor amounts of magnesium, calcium, copper, chromium and aluminium.

The iron, zinc, manganese, copper, chromium, and nickel contents, probably deriving from the scraps composition, are much higher in the furnace slags (Grey Furnace Slag, Black Furnace Slag, Total Furnace Slag), than in the ladle slags (samples Ladle Slag, Ladle Slag $>10 \mathrm{~mm}$, Ladle Slag $<10 \mathrm{~mm}$ ).

Considering the results of the particle-size and chemical characterization, the Dusts may be recycled for the electrolytic recovery of zinc and the Shavings may be recycled in counterweight and concrete production.

The reuse as inert material of the furnace and ladle slags was evaluated by means of several leaching tests, performed on the samples Total Furnace Slag and Ladle Slag, according to the Italian (DM 5/2/98 and EN12457-2), French (test AFNOR X31-210) and European Community (EN 12457-4) leaching tests.

The results of the leaching tests, reported in Tables 7 and 8, were compared with the Italian, French and Danish acceptability limits for the reuse of wastes (see Tables 1, 2 and 4) and with the European Community limits for landfill disposal (see Table 3). The results of the AFNOR X31-210 and EN 12457-4 tests were converted in $\mathrm{mg} / \mathrm{kg}$ considering a solid/liquid ratio equal to $1: 10$, to be compared with the French and European Community limits (see Tables 2 and 3).

The results of the performed leaching tests show that the sample Ladle Slag may be recycled as inert material according to French regulations, but doesn't comply with Danish and Italian limits (respectively because of the barium and nickel contents and of the barium, nickel, nitrates contents and $\mathrm{pH}$ value, outlined 
Table 7: Results of the leaching tests performed on the sample Ladle Slag

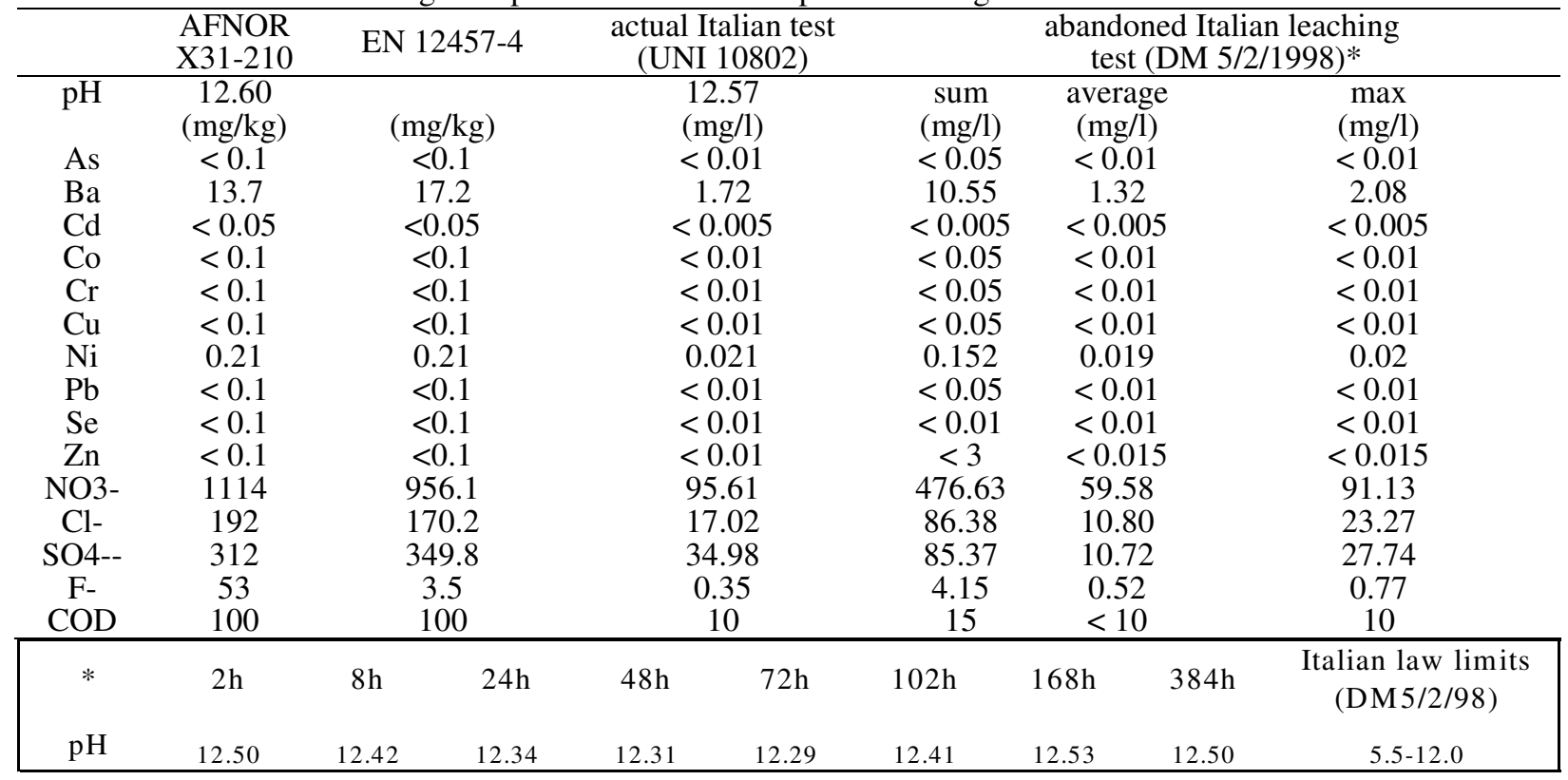

Table 8: Results of the leaching tests performed on the sample Total Furnace Slag

\begin{tabular}{|c|c|c|c|c|c|c|c|c|c|}
\hline \multirow{3}{*}{$\mathrm{pH}$} & \multirow{3}{*}{$\begin{array}{c}\text { AFNOR } \\
\text { X31-210 } \\
\begin{array}{c}12.08 \\
(\mathrm{mg} / \mathrm{kg})\end{array}\end{array}$} & \multicolumn{2}{|c|}{ EN $12457 / 4$} & \multicolumn{2}{|c|}{$\begin{array}{l}\text { actual Italian test } \\
\text { (UNI 10802) }\end{array}$} & \multicolumn{4}{|c|}{$\begin{array}{c}\text { abandoned Italian leaching } \\
\text { test (DM 5/2/1998)* }\end{array}$} \\
\hline & & \multirow{2}{*}{\multicolumn{2}{|c|}{$(\mathrm{mg} / \mathrm{kg})$}} & \multirow{2}{*}{\multicolumn{2}{|c|}{$\begin{array}{c}12.04 \\
(\mathrm{mg} / \mathrm{l})\end{array}$}} & sum & average & & $\max$ \\
\hline & & & & & & $(\mathrm{mg} / \mathrm{l})$ & $(\mathrm{mg} / \mathrm{l})$ & & $(\mathrm{mg} / \mathrm{l})$ \\
\hline As & $<0.01$ & \multicolumn{2}{|c|}{$<0.1$} & \multicolumn{2}{|c|}{$<0.01$} & $<0,05$ & $<0.01$ & & $<0.01$ \\
\hline $\mathrm{Ba}$ & 9,22 & \multicolumn{2}{|c|}{37.9} & \multicolumn{2}{|c|}{0.379} & 3.06 & 0.38 & & 0.57 \\
\hline $\mathrm{Cd}$ & $<0,05$ & \multicolumn{2}{|c|}{$<0.05$} & \multicolumn{2}{|c|}{$<0.005$} & $<0.005$ & $<0.005$ & & $<0.005$ \\
\hline $\mathrm{Co}$ & $<0.01$ & \multicolumn{2}{|c|}{$<0.1$} & \multicolumn{2}{|c|}{$<0.01$} & $<0.05$ & $<0.01$ & & $<0.01$ \\
\hline $\mathrm{Cr}$ & $<0.01$ & \multicolumn{2}{|c|}{$<0.1$} & \multicolumn{2}{|c|}{$<0.01$} & $<0.05$ & $<0.01$ & & $<0.01$ \\
\hline $\mathrm{Cu}$ & $<0.01$ & \multicolumn{2}{|c|}{$<0.1$} & \multicolumn{2}{|c|}{$<0.01$} & $<0.05$ & $<0.01$ & & $<0.01$ \\
\hline $\mathrm{Ni}$ & 0,18 & \multicolumn{2}{|c|}{0.16} & \multicolumn{2}{|c|}{0.016} & 0.102 & 0.013 & & 0.019 \\
\hline $\mathrm{Pb}$ & $<0.01$ & \multicolumn{2}{|c|}{$<0.1$} & \multicolumn{2}{|c|}{$<0.01$} & $<0.05$ & $<0.01$ & & $<0.01$ \\
\hline $\mathrm{Se}$ & $<0.01$ & \multicolumn{2}{|c|}{$<0.1$} & \multicolumn{2}{|c|}{$<0.01$} & $<0.05$ & $<0.01$ & & $<0.01$ \\
\hline $\mathrm{Zn}$ & $<0.01$ & \multicolumn{2}{|c|}{0.48} & \multicolumn{2}{|c|}{0.048} & 0.116 & 0.019 & & 0.031 \\
\hline NO3- & 216.17 & \multicolumn{2}{|c|}{153.3} & \multicolumn{2}{|c|}{15.33} & 101.23 & 12.65 & & 20.12 \\
\hline $\mathrm{Cl}-$ & 20.14 & \multicolumn{2}{|c|}{20.8} & \multicolumn{2}{|c|}{2.08} & 5.05 & 0.63 & & 1.76 \\
\hline SO4-- & 56.23 & \multicolumn{2}{|c|}{70.2} & \multicolumn{2}{|c|}{7.02} & 47.18 & 5.9 & & 12.31 \\
\hline F- & 2.82 & \multicolumn{2}{|c|}{1.8} & & & 1.9 & 0.24 & & 0.32 \\
\hline COD & 97.3 & & & & & 18 & $<10$ & & 10 \\
\hline$*$ & $2 \mathrm{~h}$ & $8 \mathrm{~h}$ & $24 \mathrm{~h}$ & $48 \mathrm{~h}$ & $72 \mathrm{~h}$ & $102 \mathrm{~h}$ & $168 \mathrm{~h}$ & $384 \mathrm{~h}$ & $\begin{array}{l}\text { Italian law limits } \\
\text { (DM5/2/98) }\end{array}$ \\
\hline $\mathrm{pH}$ & 11.67 & 11.60 & 11.75 & 11.54 & 11.42 & 11.39 & 11.27 & 11.27 & $5.5-12.0$ \\
\hline
\end{tabular}

in bold characters in Table 7). The sample Ladle Slag may be landfilled as inert waste according to European Community regulations.

On the grounds of the results of the leaching tests, the sample Total Furnace Slag satisfies French regulations but not Italian and Danish limits respectively because of the nickel content and because of the barium, nickel, nitrates and fluorides contents (outlined in bold characters in Table 8). The sample
Total Furnace Slag may be landfilled as inert waste according to European Community regulations.

Both in the case of the Ladle Slag and of the Total Furnace Slag, the contents of barium and nickel found in the leachates may be due to the scraps composition, and the concentration values of nitrates and fluorides may derive from the lime, used as slag making agent in the casting furnace and as desulphurizing additive in the ladle furnace. 
The data shown in Tables 7 and 8 allow further considerations about the leaching tests procedures: the results of the AFNOR X31-210 test are comparable but lightly higher than the ones of the EN 12457/2-4 tests, probably because of the superior stirring speed and of the lower particle-size dimensions allowed for the waste. The results of the AFNOR X31-210, EN $12457 / 4$ and UNI 10802 tests are of the same magnitude order of the average results of the Italian test. The authors think that a comparison of the sum of the results analysed in eight leachates with the law limits has no sense, and that the procedure of the Italian test is too long and expensive. A revision of the Italian leaching test has happened in 2006, and the UNI 10802 test (equivalent to EN 12457-2 test), that is already adopted in Italy to evaluate the landfill disposal, has recently substituted the DM 5/2/98 leaching test, even if keeping the same concentration limits.

\section{CONCLUSION}

On the grounds of the performed study the authors may formulate the following considerations about the recycling of the wastes of the considered steelmaking plant:

the dusts coming out from the dust treatment plant (containing about the $29 \%$ of zinc) may be sold for the electrolytic recovery of this metal; the oxidized shavings from the cut operations may be sold, or reused in the casting process of the steelmaking plant; the ladle and furnace slags may be recycled as inert material in France, although a transport cost equal to about $8 € / \mathrm{t}$ from the steelmaking plant to the French border must be taken in account.

Actually in Europe the landfilling costs for the considered wastes may vary from $50 € / \mathrm{t}$ to $150 € / \mathrm{t}$; in this work the recycle of 143,000 t/y of industrial wastes coming out from a steel foundry located in northern Italy is proposed, hypothesizing a saving of 7,150,000$21,450,000 € / y$.

\section{REFERENCES}

1. United States Environmental Protection Agency 1995, Profile of the iron and steel industry, Office of Compliance Sector Notebook Project, EPA 310R-95-005. 